\title{
The Play of Cupak Gerantang in Wayang Kulit and Traditional Dramas and Values in Balinese and Sasak Society in Lombok
}

\author{
Luh Putu Puspawati ${ }^{1 *}$, I Made Suastika ${ }^{1}$ \\ ${ }^{1}$ The Faculty of Cultural Science Udayana University, Denpasar, Bali, Indonesia \\ *Corresponding author. Email: puspawati1960@yahoo.co.id
}

\begin{abstract}
The play of Cupak Gerantang is an oral tradition in Bali and Lombok, but this story has integrated and adapted to the people of Bali and Lombok. In subsequent developments, the oral story of the Cupak Gerantang was used in plays in the art of wayang kulit performances in Bali and traditional drama plays in Lombok. These two stories have values that can be understood and accepted by society, such as: educational values, morality values, and ethical values. The figure of Cupak Gerantang in Bali is used as a personification of two brothers who have different faces, if the Cupak character has a bad face, the evil nature is greedy and slander. If the Gerantang character has a handsome face, is well mannered and thoughtful, diligently likes to help respect his parents. Whereas in Lombok the value of the Cupak Gerantang story is symbolic of local community groups and the aristocracy. Cupak Gerantang is understood by Balinese as a figure differently in Bali. Represented as two brothers and sisters. In Lombok the figure of Cupak Gerantang is represented as a characteristic of the Sasak people having a different stratification. Cupak is rude, stiff, arrogant, slanderous, likes to show off. Gerantang is the personification of aristocrats, has a refined nature, is handsome, and likes to work hard and is a noble of Javanese descent.
\end{abstract}

Keywords: Play, Cupak Gerantang, Oral Tradition

\section{INTRODUCTION}

Folk stories that have been transmitted orally by the Balinese and Sasak people in Lombok to date have been packaged in the form of performances. There is one form of performance that has its own appeal to the community, namely the Cupak and Gerantang performances. This performance, as the name implies, takes the play Cupak Gerantang. This play began as a sleeping fairy tale that parents usually tell to their children or grandchildren. The fairy tales are similar to the banner stories in Java. The story is passed down from generation to generation by the community because it contains very noble values that can be used as a guide for life. Since the past these stories were spoken verbally and had such an appeal that they became popular among Balinese and Lombok people.

Based on the above phenomena, oral traditions that are passed from one generation to the next are carried out through spoken language using speech instruments. Meanwhile, Vansin states that oral tradition is a process of creating messages and it also contains the dynamics of the oral history process [1]. Oral tradition as the process of delivering messages and in this case, in this case, no other human in carrying out a conversation produces a message that tends to be repeated so that it can be identified as the beginning of a delivery process.

Meanwhile, Suastika revealed that in the oral tradition there is oral literature [2]. Oral literature is in the form of oral stories that can still be maintained in a number of rural areas, especially in the communities in Bali. This tradition has the function of having the function of passing on the noble values of their ancestors from the past. In addition to having very high aesthetic or aesthetic values, oral literature also contains cultural, didactic, social and religious values which are very useful to improve the quality of human life.

In line with the above expression, one of the oral traditions that are still preserved in the life of the Balinese and Sasak people in Lombok is an oral story that takes the character of Cupak-Gerantang. Apart from being conveyed through fairy tales, oral literary art is also 
displayed in performance art creations that are staged in several important events. The performance of oral literature is still being performed because it has appeal and value among the audience.

Based on the description above, this paper presents the oral tradition which is actualized through the oral literary art which takes the play Cupak-Gerantang. According to the narrative of a number of Balinese and Lombok cultural figures, the story is an event that occurred in the past in North Lombok during the reign of the Daha Kingdom, whose people embraced Buddhism. The story took place in the Bayan area, namely in Senaru Village. The delivery of the Cupak-Gerantang story through oral literature is not only a spectacle but also a media for guiding people to behave in the midst of their daily lives. In Bali it is performed in the wayang kulit play Cupak-Gerantang in all areas in Bali, however the Cupak-Gerantang shadow puppets are very thick in the Tabanan area in Jelijih Village.

\section{METHODS}

\subsection{Research Design}

This research is qualitative in nature, the object of research is the story of Cupak-Gerantang in Bali and Lombok. In Bali, plays are used in wayang kulit performances, and in Lombok in the classic drama Cupak-Gerantang. The research stages are divided into several stages, namely: (a) data collection stages, (b) data processing stages, (c) stages of data analysis, (d) tages of writing research results.

The stages of data collection were carried out by surveying the field, observing and non-participating and interviewing a number of community leaders as informants both in Bali and in Lombok. During the survey in the field, observations were made at the research location. Data were collected in the form of interviews and observations and then reduced, sorted according to needs. Then do the writing of the final report on the results of the research which is the result of field data interpretation. In this research, the theory used is the theory of structure and theory of values.

Regarding the research locations are in Bali and Lombok. The informants were determined by purposive sample by considering the availability of data. Informants include community groups who understand the CupakGerantang story, so that the first informants selected were key informants who were developed using the Snowbal technique. Then the key informant appointed the next informant until the data was saturated.

\section{FINDINGS AND DISCUSSION}

\subsection{Synopsis of the story of Cupak Gerantang in Lombok}

The story of Cupak-Gerantang describes two characters, namely Cupak as an antagonist and Gerantang as a protagonist. These two people are brothers and these two figures lived during the Buddhist kingdom of Daha which developed around the 9th century AD. This kingdom was in the Bayan Barat area which is now Senaru Village. The kingdom of Daha was led by a king named Datu Daha. Datu Daha was accompanied by two very powerful patih, one named Patih Mangku Bumi and the other named Patih Mangku Negara. Datu Daha has a very beautiful daughter named Dewi Sekar Nitra.

Once upon a time Dewi Sekar Nitra who was playing in the palace garden was then kidnapped by a giant. Although Patih Mangku Bumi and Patih Mangku Negara have tried to fight the giant, they have been unsuccessful. Then Dewi Sekar Nitra was rushed into the forest by the giant.

It is told that two nomads named Cupak and Gerantang traveled through the Daha region and at that time they heard that there was a competition held by Datu Daha which in essence would give a part of the kingdom and would marry Dewi Sekar Nitra as a gift if they could defeat the giant who had kidnapped Dewi Sekar Nitra.

The existence of this contest moved Cupak's heart to invite his younger brother to join the competition. They faced Datu Daha and Cupak agreed to kill the giant and return Dewi Sekar Nitra to the Daha Kingdom. Even though Gerantang had reminded his brother not to recklessly comply with Datu's orders. Finally, Datu Daha handed over a magic keris to Cupak to use against the giant. Furthermore, Cupak and Gerantang were escorted by Patih Mangku Bumi and Mangku Negara who were followed by their soldiers to the limits of the kingdom. In the forest Cupak and Gerantang enter the wilderness and after weeks of walking through the forest they finally meet the giant who kidnapped Dewi Sekar Nitra. From an unknown direction came a very large and thundering voice which was none other than the voice of a giant kidnapping Dewi Sekar Nitra and hiding her in an old well in the middle of the jungle. Hearing such a loud voice, Cupak ran peeing and invited Gerantang to leave the wilderness. However, Gerantang refused and instead he challenged the giant to a fight. Thanks to his courage and supernatural powers, finally Gerantang can knock down the giant.

Furthermore, Cupak and Gerantang agreed to take Dewi Sekar Nitra hidden in an old well. Finally Cupak asked his sister to come down to take Dewi Sekar Nitra by holding on to the rope that Cupak had held at one end. Finally, after Dewi Sekar Nitra was lifted from the well, 
Cupak broke the rope, finally it was Cupak who succeeded in bringing Dewi Sekar Netra to Datu Daha. Furthermore, Datu Daha will give a gift to Cupak for the success he has achieved.

Meanwhile Gerantang with difficulty finally got up from the old well which followed his brother to the palace of the Daha Kingdom. Very sadly, Cupak did not acknowledge his younger brother Gerantang because he wanted to marry Dewi Sekar Nitra and become King in the Daha Kingdom. In order to make the plan smooth, finally Patih Mangku Bumi and Patih Mangku Negara killed Gerantang and threw them into the river.

It is told that there were two husband and wife farmers who found Gerantang by the river. After being observed, it seems that Gerantang is still alive and eventually adopted and made a child by the husband and wife. It was told at the palace of the Daha Kingdom that there was a battle of strength and a fighting competition. In this fight Cupak challenged anyone who dared to defeat him to replace him as a candidate for king. In this battle, nothing can match the strength of Cupak.

The news about the peresehan fight was heard by a husband and wife who picked up Gerantang. They intend to invite Gerantang to watch the peresehan fight. Arriving there in the Kingdom of Daha, Cupak was so surprised to see Gerantang coming and finally he did not dare to fight Gerantang, because Gerantang was known to have greater abilities than Cupak. And at the same time Dewi Sekar Nitra came and saw Gerantang's presence in that place. He told Datu Daha that Gerantang was the one who managed to save himself from a giant kidnapping in the middle of the forest. In the end, Gerantang was summoned to receive a competition prize to be married to Dewi Sekar Nitra and would become a Datu in the Daha Kingdom. Meanwhile, Cupak realized his mistake and he left the Daha Kingdom.

\subsection{Synopsis of the Cupak Gerantang Wayang Kulit in Bali}

The story of Cupak-Gerantang in Bali is very well known and has long been passed down by the community, especially in mesatua activities, as a tradition of telling stories when parents put their children to bed. Also used as a wayang kulit performance performed by the puppeteer Jangga from Tabanan. There was also a Cupak-Gerantang puppet staged at the Majelangu Banjar Babakan Penebel Tabanan temple and staged in the Arja play in the context of the 2016 Bali Arts Festival.

The text of the Cupak-Gerantang was performed in the wayang play Cupak-Gerantang. This story was very popular around the 1960s. At that time the puppeteer of Cupak was called Cupak-Gerantang. The puppeteer of Cupak-Gerantang is called the Dalang Jangga from
Bunut Puhon Village, Selemadeg Tabanan District. His performances were very popular in those years almost every night in various villages in Tabanan. So famous was the performance of the Cupak puppet with the typical Tabanan jokes, although in the end the Jangga dalang was used as a political promotion at that time.

In its performance, the story begins with the characters of two brothers, I Cupak and I Gerantang. In the journey of these two figures, there is always controversy in terms of character, face, character and behavior. I Cupak is a character who has a short stature, fat, red body, fast hair. In speaking, I Cupak always shows arrogance and considers problems to be easy, such as when I was going to kill I Menaru. The character of I Gerantang, on the other hand, has a handsome face, has a delicate warning, his speech is very polite and intelligent.

It is told that as an adult, I Cupak always tricked I Gerantang hail. This was done several times when plowing in the fields and I Cupak always played. Likewise, when I was about to kill I Menaru, I Cupak thought I Menaru was small like a Alu (a small monitor lizard), after seeing the fact that I Cupak was afraid to just see his feces and urine. The one who killed I Menaru and freed Raden Galuh was I Gerantang, but I Cupak stated that he was the one who killed I Menaru.

Another thing that made the character I Cupak controversy with I Gerantang when he went to King I Cupak admitted that he killed I Menaru. As a gift, I Cupak was married to the beautiful Raden Galuh. It turned out that this marriage made I Cupak rule in the Kediri Kingdom. I Gerantang hurt and suffered due to the actions of his brother I Cupak when he was about to go up from the cave. I Menaru was cut off his rope so he fell and entered the cave again. I Gerantang suffered and only a few days was able to get out of the cave thanks to Hyang Kuasa's help.

At the end of the story, I Cupak Gerantang, I Gerantang came to the palace of the Kingdom of Kediri and announced that he was the killer of I Menaru, but I Cupak tricked I Gerantang and tied him up and threw him into the sea. However, I Gerantang was rescued by fishermen and adopted as a child. News spread that I Gerantang was still alive and known to have killed I Menaru, so he came to the Kediri Palace and met Raden Galuh by showing the ring he was wearing. Finally, I Gerantang lived happily with Raden Galuh as husband and wife and I Gerantang was appointed king in the Kingdom of Kediri.

\subsection{The Cupak Gerantang Story Performance Structure}

In the story play, Cupak-Gerantang has a structure, namely the Cupak and Gerantang characters and several other characters. The figure of Cupak-Gerantang is 
depicted by two controversial figures, namely the figure of Cupak who has an ugly face, has a rough grin, is lazy, likes sleeping and snoring, cunning. While Gerantang has a handsome face, is diligent, he said smooth, smooth white skin, likes to help, has an ideal body posture so that people really like him. These two characters become the part of the story line and center until the story ends.

The story line of Cupak-Gerantang has a straight pestle or is called advanced, namely the story from the beginning of the two Cupak Gerantang characters from where he lived with his family, he wandered into the Kingdom of Kediri. In the Kingdom of Kediri he participated in a competition to free Raden Galuh even though Gerantang was deceived by Cupak, because in fact the one who killed I Menaru was Gerantang but himself (Cupak) who admitted it. Cupak finally admitted that the one who killed I Menaru was I Gerantang, not himself, finally Gerantang was married to Raden Galuh and became the King of Kediri.

The incident that was raised brought the story forward from the beginning of the story to the ending, namely the incident of the character Cupak who was lazy to work in the fields but slandered the character Gerantang who was diligent. Then the incident when he wandered to the Kingdom of Kediri and joined the competition to free Raden Galuh from the clutches of I Menaru. In this incident, Cupak's character again cheated by saying that I Menaru killed himself. Cheating that was committed by means of the Gerantang straps during the fight with I Menaru was cut off after I Menaru died and Raden Galuh was released while Gerantang entered the cave again. The next incident Cupak was given a gift by the King of Kediri, but the closing incident was that Cupak admitted his mistake with the Gerantang character showing the ring given by the King of Kediri before fighting against I Menaru.

The settings in this story are the houses of Cupak and Gerantang, Kingdom of Kediri and Daha, forests and caves where the giant I Menaru, the beach, the hut where the husband and wife pick up Gerantang when he drifts away on the coast. Meanwhile, the theme of the Cupak Gerantang story is "good will defeat evil", which in the end Gerantang is on the right and honest side even though he was tricked several times, slandered, lied to, persecuted by the figure of Cupak but the truth won. The mandate of the Cupak Gerantang story is to do honestly with your conscience, don't like to slander, greedy, greedy, all of this will have karma, do goodness, fame will wait.

The structure of the play Cupak-Gerantang based on the performance of wayang kulit in Bali and dance drama in Lombok is almost similar to these two stories.

The story of Cupak-Gerantang which has been integrated with the Sasak community as well as in Bali according to the synopsis above is a very interesting story to be listened to. At first this story was a fairy tale that was told by parents to their children and grandchildren at bedtime. The tradition of storytelling in the Sasak people and Balinese people is a custom that is done to entertain children before they fall asleep. This happened to the Sasak people and Balinese people in the past. As for the background that is the driving factor for the strong public interest in listening to the story is the lack of entertainment among them.

The inclusion of external cultural influences is a very influencing factor in the use of the oral tradition, especially storytelling, which is increasingly being used by parents to their children. At the same time, the influence of Balinese culture in Sasak was introduced when the Karangasem kingdom was ruled in Lombok. The culture is a performing art. Among the Sasak people, they also create performing arts using local wisdom that exists in the Sasak community. In this connection, the Balinese and the Sasak people have cultural contact. So that there is a Balinese cultural identity used by the Sasak people and also the local wisdom of the Sasak people which has colored the cultural systems of Bali and Lombok.

Based on the above phenomena, cultural contact occurs to be the cause of dynamics in a culture. In culture, messages are also very important in bringing about a change towards improvement. In line with that, Vansina states that every message is part of culture [1]. These messages are expressed in the language of a culture and are conceived and understood in cognitive and substantive terms from a culture. Because culture shapes all messages and we must take this into account when we interpret those messages.

The emergence of performing art creations in the Balinese and Sasak people by involving the local wisdom of the Balinese and Sasak people, one of which is manifested in the form of visual arts. The performing arts he creates take on plays that have become popular in the community in the lives of Balinese and Sasak people. One of the plays raised in the traditional performing arts is Cupak-Gerantang. This story is very popular among the people of Bali and Lombok because the storyline features antagonist and protagonist characters.

In the traditional Cupak-Gerantang performance, these figures are well visualized. This indicates that there are two black-and-white characters. Cupak as his brother with an antagonistic character symbolizing a personal figure who is greedy, cheating, related to the identity of crime. Cupak is depicted in his physical form as a greedy man, with a distended stomach. On the other hand, Gerantang is a protagonist who is symbolized by a manly, kind, and wise person. This character is visualized with good looks.

The traditional Cupak-Gerantang performance is generally performed to entertain the public on certain 
days. If there is a party or ceremony, the CupakGerantang is staged, accompanied by gambelan. Generally, the public already knows the storyline, but when there is a performance the audience is always crowded. Those who watch are not limited by age.

This phenomenon is an indicator that the oral tradition, which was originally a sleeping fairy tale, was told to their children or grandchildren before they grew up in Balinese and Sasak people. The story of cupakgerantang whether it is conveyed through sleep tales or which is packaged in traditional art forms still shows the existence of oral traditions. With regard to the oral tradition in the Cupak-Gerantang story, it has its own appeal among the Balinese and Lombok people.

\subsection{Values in the play of Cupak Gerantang}

With regard to the appeal of the Cupak Gerantang story to the people of Bali and Lombok, both in the form of sleeping tales and traditional performing arts, there are values that can be used as a guide for life. One of the implicit values behind the oral tradition in the play Cupak Gerantang is ethical value. Ethical values are related to the moral values that underlie human actions. Referring to Bartens who argues that ethics is a moral value that underlies human behaviour [3]. In another part, ethics as a reflection is defined as a thought or moral philosophy. In this connection, humans think or reflect about what to do and how humans behave in concrete situations. Meanwhile Sura defines ethics as a form of self-control in social life together [4]. Humans are homo socius creatures who always need other humans to live and develop naturally and must regulate themselves to behave in effect. Thus, people are free to act in the bonds of rules of good behavior.

In connection with the oral tradition of CupakGerantang, whether it is conveyed through sleep tales or which has been packaged in the performing arts, it has provided teachings about ethics as a basis for acting. The ethical teachings conveyed in the play Cupak-Gerantang are packed with figures of Cupak and-Gerantang. The character of Cupak represents bad ethics. This is shown in the story with antagonistic characters such as greed, cheaters, con artists and slander. The actions presented in the figure of Cupak give lessons to the public about the evils that must be avoided when interacting in the community. The characters displayed by Cupak tend to bring badness to individual life in the midst of their social environment.

In contrast to the character shown by Cupak, in the figure of Gerantang, it represents an attitude and action that must be imitated. Judging from the ethical aspect of action displayed by Gerantang, it is full of good ethics because it symbolizes good character, noble, wise, and all actions with good identities. This becomes a teaching in building an ideal life and in the hands of the community.
The ethics presented in the Cupak Gerantang story above are associated with the purpose of life, which are guidelines for behavior in realizing harmony. Referring to Suhardana states four goals to be achieved in realizing a noble and noble life [5]. The purpose of life is associated with the teachings of Hinduism. First, to foster Hindus so that they can maintain good relationships, live in harmony and harmony, both with their families and with other oranges. Second, to avoid the existence of the law of the jungle, namely the strong oppress or manipulate the weak. Third, to nurture Hindus to become good and virtuous human beings. Fourth, to foster Hindus always behave and behave well, including doing good with anyone.

Ethics in Hinduism is also known as morality. With this regard, Mantra defines moral order as rules of good and noble behavior that must be used as a guide for human life [6]. Ethical order aims to maintain a harmonious and harmonious relationship between human beings in order to create a safe and secure community life.

With regard to the above phenomena, sleep tales and traditional performing arts in taking the Cupak Gerantang story as a medium for conveying messages to the next generation which are conveyed orally or using existing instruments. This oral tradition contains the values of messages conveyed to the public. This is in line with Vansina's statement which explains that oral traditions are verbal messages which are statements from the past that surpass the present [1]. This definition requires that the messages must be in the form of spoken messages that are spoken, sung or mentioned with a musical instrument in wayang performances and traditional drama performances.

\section{CONCLUSIONS}

Based on the description displayed in the play Cupak Gerantang in the middle of the life of the Balinese and Sasak people in Lombok, whether packaged in the form of sleeping tales or traditional performing dramas are important media in teaching the values used as guidelines life. Although the stories told are still traditional in nature, they have an important meaning for the lives of individuals and groups of people. The values that are important in these teachings are ethical values. This is related to the behavior that must be upheld when interacting in the community. This behavior is based on kindness and truth to create a harmonious community life. The high interest of Balinese and Lombok people in listening to these oral traditions is an indicator that oral traditions are still alive and are preserved as ancestral heritage which has an important meaning in order to improve the quality of human life, both individually and as a group.

The play of Cupak-Gerantang as a form of oral tradition, whether presented through sleep stories or in 
the form of traditional performances, is an effective learning medium in order to build awareness to improve one's quality. This shows that the oral tradition presents a model of learning through entertainment. In this case the Cupak Gerantang oral tradition is an alternative that can be used to make people aware of upholding ethical values and morality in their actions.

\section{REFERENCES}

[1] J. Vansina, Tradisi Lisan sebagai Sejarah, in: A. Reza, et. al. (Translation), Yogyakarta: Ombak, 2014.

[2] I. M. Suastika, Tradisi Sastra Lisan (Satua) di Bali: Kajian Bentuk, Fungsi, dan Makna, Denpasar: Pustaka Larasan, 2011.

[3] K. Bertens, Etika, Jakarta: Gramedia, 2004.

[4] I. G. Sura, Pengendalian Diri dan Etika dalam Ajaran Agama Hindu, Jakarta: Hanuman Sakti, 2001.

[5] K. M. Suhardana, Pengantar Etika dan Moralitas Hindu: Bahan Kajian untuk Memperbaiki Tingkah laku, Surabaya: Paramita, 2016.

[6] I. B. Mantra, Tata Susila Hindu Dharma, Denpasar: Upada Sastra, 1992. 